\title{
Effects of Spiro-bisheterocycles on Proliferation and Apoptosis in Human Breast Cancer Cell Lines
}

\author{
LAMIA HAMDAN RAMDANI ${ }^{1,2,3}$, OUALID TALHI ${ }^{1,5}$, NADIA TAIBI ${ }^{1}$, \\ LAETITIA DELORT $^{2,3}$, CAROLINE DECOMBAT ${ }^{2,3}$, ARTUR SILVA ${ }^{5}$, KHALDOUN BACHARI $^{1}$, \\ MARIE-PAULE VASSON ${ }^{2,3,4}$ and FLORENCE CALDEFIE-CHEZET ${ }^{2,3}$ \\ ${ }^{1}$ Scientific and Technical Research Center in Physico-Chemical Analysis (CRAPC), Tipaza, Algeria; \\ ${ }^{2}$ Clermont University, University of Auvergne, UMR 1019, UNH CellulaR Micro-Environment, \\ Immunomodulation and Nutrition ECREIN, Clermont-Ferrand, France; \\ ${ }^{3}$ Research Center in Human Nutrition CRNH Auvergne, Clermont-Ferrand, France; \\ ${ }^{4}$ Anticancer Center Jean-Perrin, Clermont-Ferrand, France; \\ ${ }^{5}$ Organic Chemistry, Natural Products and Agrifood (QOPNA), \\ Department of Chemistry \& QOPNA, University of Aveiro, Aveiro, Portugal
}

\begin{abstract}
Breast cancer is the leading cause of cancerrelated death in women worldwide and a critical public health concern. Here we investigated the anticancer potential and effects of low-molecular-weight bridgehead oxygen and nitrogen-containing spiro-bisheterocycles on proliferation and apoptosis of the human breast cancer cell lines MCF-7 and MDA-MB-231. The compounds feature a hydantoin moiety attached to either diazole, isoxazole, diazepine, oxazepine or benzodiazepine via the privileged tetrahedral spiro-linkage. Treatment with compounds spiro [hydantoin-isoxazole] and spiro [hydantoin-oxazepine] resulted in a dose-dependent decrease of cell proliferation and induction of apoptosis in both breast cancer cell lines, whereas spiro [hydantoin-diazepine] was only active against $M D A-M B$ 231. Quantitative reverse transcription polymerase chain reaction analysis showed up-regulation of murine double minute 2 (MDM2), strictly p53-dependent, and detected an increase in expression of pro-apoptotic caspase 3 and BCL2-associated $X(B A X)$ genes in both breast cancer cell lines expressing wild-type and mutant p53. In summary, the results suggest that our compounds promote apoptosis of breast cancer cell lines via p53-dependent and-independent pathways.
\end{abstract}

Correspondence to: Lamia Hamdan Ramdani, Scientific and Technical Research Center in Physico-Chemical Analysis CRAPC, BP 384, Industrial zone of Bou-Ismail, RP 42004, Tipaza, Algeria. E-mail: lamia_pharm@yahoo.fr

Key Words: Spiro-bisheterocycles, oxygen and nitrogen heterocycles, breast cancer, cell proliferation, apoptosis, p53, MDM2.
Breast cancer is the most common invasive cancer in women and the leading cause of cancer-related death in women worldwide, making it an urgent public health issue (1). Despite intensive research into new chemotherapeutic agents, treatment is still characterized by unwanted side-effects and the spread of drug resistance, and thus falls short of expectations (2). Consequently, it is essential to pursue the drug development effort to treat breast cancer cells.

Many spiro compounds play fundamental roles in biological processes and have demonstrated therapeutic properties. (3), especially the spiro-heterocyclic compounds, which have shown promising results in chemotherapy of various cancer types (4). Spiro compounds are usually a structural system of two rings positioned orthogonally one to the other due to the $\mathrm{sp}^{3}$ hybridization of the central spiro carbon, which can be chemically adjusted by introducing various heterocyclic motifs mimicking those found in biomolecules, such as DNA and proteins, in order to increase their ability to interact with biological systems. This very rare spatial arrangement of spiro-bicyclic scaffolds is characterized by high rigidity, preventing freely-rotating bonds, which can also be configured with several essential functional groups.

Spiro functionality also remains a primary structural tool for creating powerful molecular antitumor and anticancer agents used in latest-generation chemotherapy. Nature provides outstanding spiro structures, as evidenced by the discovery of new spiro-bicyclic triterpenoid models were found to be cytotoxic against breast human cancer cell lines (5). However, the low natural availability of spiro compounds has prompted researchers to build on these molecular templates to optimize novel spiro-based chemical structures capable of significant bioactivity. 
In this context, researchers have successfully used tetrapeptide recognition motifs in order to prepare core systems of 5.5 spiro-oxindoles (Figure 1A) and 6.5.5 spiro-bicyclic lactams (Figure 1B) capable of affecting protein-protein interactions for use as an efficient strategy in cancer therapy (6). Various spiro-isoxazolidine (Figure 1C) derivatives were prepared and tested for their anticancer activity against human cancer cell lines. Moreover, several 4-bromo spiro-isoxazoline structures have also shown antiproliferative effects against breast and prostate cancer cell lines (7).

The transcription factor tumor suppressor p53 is one of the main mediators regulating the cell cycle and induction of apoptosis in response to cellular damage (9). p53 regulation in the cell is essentially based on its negative regulator murine double minute 2 (MDM2). Targeting p53-MDM2 interaction by using appropriate molecules offers an attractive strategy for p53 activation (8) and a promising approach for new anticancer therapies (10).

Previous studies have reported that spiro compounds are potent antagonists of the p53-MDM2 interaction (6). Given these biorelevant properties, spiro compounds make very attractive targets for cancer treatment screening. Here we provide an account of the evaluation of our previously reported small molecules containing oxygen and nitrogen spiro-bisheterocycles in terms of effects on in vitro proliferation and apoptosis of human breast cancer cell lines (MCF-7 and MDA-MB231). The wider aim is to identify novel low-molecular-weight, easily-accessible synthetic spiro compounds for cancer chemotherapy.

\section{Materials and Methods}

Chemistry. Spiro-bisheterocyclic compounds 2-7 (Table I; Figure 2) were chemically synthesized following our previously described procedure (11). Their preparation is based on the action of bisnucleophiles such as methylhydrazine, hydroxylamine, ethylenediamine, hydroxyethyleneamine and ortho-phenylenediamine on the key spiro[chromanone-hydantoin] (1) dyad, which results in a spiro-to-spiro ring transformation of the chromanone residue into new substituted spiro[hydantoin-diazole] (2), spiro[hydantoin-isoxazole] (3), spiro[hydantoin-diazepine] (4-5), spiro[hydantoin-oxazepine] (6) and spiro[hydantoin-benzodiazepine] (7) (Figure 2). During these chemical reactions, the hydantoin cycle is preserved, as confirmed by relevant 2D nuclear magnetic resonance and single-crystal X-ray diffraction studies. Our spiro-bisheterocycles (2-7) were produced in optimal $42-67 \%$ yields after chromatographic purification and recrystallization, thus affording high purity as checked by TLC showing a single spot.

Cell culture and treatment. MCF-7 and MDA/MB 231 human breast adenocarcinoma cell lines were purchased from the American Type Culture Collection (Molsheim, France). MCF-7 and MDA-MB-231 were grown in RPMI-1640 and L-15 medium (GIBCO, Invitrogen, Saint-Aubin, France), respectively. RPMI-1640 medium was supplemented with $10 \%$ heat-inactivated fetal bovine serum (FBS) (Eurobio, Courtaboeuf, France), 1\% L-glutamine (2 mM) (GIBCO,
Table I. Structures and experimental data of spiro-bisheterocycles 2-7 (11).

\begin{tabular}{|c|c|c|c|}
\hline Compound & Structure & Molecular weight (g/mol) & Yield (\%) \\
\hline 2 & 424.55 & 61 \\
\hline 3 & 438.57 & 42 \\
\hline 5 & & & \\
\hline
\end{tabular}

Invitrogen, Saint-Aubin, France), $0.5 \%$ gentamycin $(50 \mathrm{mg} / \mathrm{ml})$ (Fisher Scientific, Strasbourg, France) and $0.05 \%$ insulin (100 UI/ml). Fluoresceinisothiocyanate (FITC) conjugated to annexin $\mathrm{V}$ was purchased from BioLegend (San Diego, CA, USA) and propidium iodide (PI) was purchased from Biotium (Hayward, CA, USA). A $10 \mathrm{mM}$ stock solution of compounds 2-7 was prepared in dimethylsulfoxide (DMSO) and stored at $4{ }^{\circ} \mathrm{C}$. All compounds were added to cells at different concentrations. The DMSO concentration of controls was $<0.1 \%(\mathrm{v} / \mathrm{v})$ and $1 \mu \mathrm{M}$ doxorubicin was used as a positive control.

Cell proliferation assay. Cell proliferation was assessed by resazurin assay. Human breast adenocarcinoma cell lines $\left(1 \times 10^{4} /\right.$ well $)$ were cultured in 96-well plates with complete media for $24 \mathrm{~h}$. At the end of incubation, cells were treated with compounds 2-7 at concentrations of $0,10,25,50$ and $100 \mu \mathrm{M}$ for $72 \mathrm{~h}$ at $37^{\circ} \mathrm{C}$ under a $5 \% \mathrm{CO}_{2}$ atmosphere without replacing the medium. Control cells and positive control cells were treated with $0.1 \%$ DMSO and $1 \mu \mathrm{M}$ doxorubicin, respectively. After incubation, $200 \mu \mathrm{l}$ of a $25 \mu \mathrm{g} / \mathrm{ml}$ solution of resazurin in medium was added to each well. Plates were incubated for $2 \mathrm{~h}$ at $37^{\circ} \mathrm{C}$ in a humidified atmosphere containing 5\% $\mathrm{CO}_{2}$. Fluorescence was then measured on an automated 96-well plate reader (Fluorskan Ascent FL; Thermo Fisher Scientific, Wilmington, $\mathrm{NC}$, USA) at $530 \mathrm{~nm}$ excitation wavelength and $590 \mathrm{~nm}$ emission wavelength. Under these conditions, fluorescence (OD value) was proportional to the number of living cells in the well. Cell 
<smiles>CC(C)(C)C[C@H]1N[C@H](C(=O)NCCN2CCOCC2)[C@@H](c2cccc(Cl)c2F)[C@@]12C(=O)Nc1cc(Cl)ccc12</smiles>

A<smiles>COC(=O)C1CSC2CC3(CCCCN3C(=O)OC(C)(C)C)C(=O)N21</smiles>

B<smiles>CC1=C2C3OC(=O)C4(CC([Al])N(c5ccccc5)O4)C3CCC2(C)C=CC1=O</smiles>

C

Figure 1. Synthetic spiro-bicyclic compounds as anticancer agents: A: 5.5 spiro-oxindoles; B: 6.5 .5 spiro-bicyclic lactams; and C: spiroisoxazolidine.<smiles>[R]N1C(=O)N([R])C2(CC(c3ccccc3O)=NCCO2)C1=O</smiles>

(i) Methylhydrazine, $\mathrm{CH}_{2} \mathrm{Cl}_{2} / \mathrm{RT}$

(ii) Hydroxylammonium chloride, 3eq $\mathrm{K}_{2} \mathrm{CO}_{3}$, THF/Reflux

(iii) Ethylenediamine, $\mathrm{CH}_{2} \mathrm{Cl}_{2} / \mathrm{RT}$

(iv) Hydroxyethyleneamine, $\mathrm{CH}_{2} \mathrm{Cl}_{2} / \mathrm{RT}$

(v) Ortho-phenylenediamines, Cat. DBU, THF/Reflux<smiles>[R]N1C(=O)N([R])C2(CC(c3ccccc3O)=NN2C)C1=O</smiles>

(ii)<smiles>[R]N1C(=O)N([R])C2(CC(c3ccccc3O)=NCCN2)C1=O</smiles><smiles>[R]N1C(=O)N([R])C2(CC(c3ccccc3O)=NO2)C1=O</smiles><smiles>[R]=CC1CCCCC1</smiles>

Figure 2. Reaction pathway for the synthesis of spiro-bisheterocycles 2-7 (11). RT: Room temperature; DBU: 1,8-diazabicyclo[5.4.0]undec-7-ene; THF : tetrahydrofuran.

proliferation assays were performed at least six times for each cell line (in replicates of six wells per concentration tested) (12).

DNA quantification using Hoechst 33342. 96-Well plates containing treated and control cells were taken out of freezer storage at $-20^{\circ} \mathrm{C}$ and left to defrost for $1 \mathrm{~h}$ at room temperature. Then, $100 \mu \mathrm{l}$ of $0.01 \%$ sodium dodecyl sulfate was added to enable the DNA to come into contact with the Hoechst solution. After $1 \mathrm{~h}$ of incubation, plates were put back in the freezer at $-80^{\circ} \mathrm{C}$ for $1 \mathrm{~h}$ to trigger thermal shock. After defrosting for $2 \mathrm{~h}, 100 \mu \mathrm{l}$ of Hoechst solution $33342\left(30 \mu \mathrm{g} \mathrm{ml}^{-1}\right)$ was added to each well. Plates were placed under agitation for $1 \mathrm{~h}$ shielded from light. The reading of the fluorescence was made by Fluorskan Ascent FL (Thermo Fisher Scientific). Hoechst 33342 dye is a fluorescent nucleic acid which exhibits a maximum emission at $460 \mathrm{~nm}$ when bound specifically to double-stranded DNA. Data represent viable cells.

Annexin V-FITC/PI apopstosis assay. MCF-7 and MDA-MB 231 tumor cells $\left(10^{5}\right.$ cells/well) were treated with $100 \mu \mathrm{M}$ of compounds 3,4 and 6 for $72 \mathrm{~h}$ at $37^{\circ} \mathrm{C}$ andwith $5 \% \mathrm{CO}_{2}$, then washed with phosphate-buffered saline, recovered by centrifugation at $1,000 \times g$ for $5 \mathrm{~min}$ at room temperature $\left(\mathrm{RT} ; 25^{\circ} \mathrm{C}\right.$ ), and resuspended in $40 \mu \mathrm{l}$ 
Table II. Primer sequences.

\begin{tabular}{|c|c|c|}
\hline Target gene & Name & Primer sequences \\
\hline \multirow[t]{2}{*}{$p 53$} & \multirow[t]{2}{*}{ Tumor protein $\mathrm{p} 53$} & F: TCAGTCTACCTCCCGCCATA \\
\hline & & R: TTACATCTCCCAAACATCCCT \\
\hline \multirow[t]{2}{*}{$M D M 2$} & \multirow[t]{2}{*}{ Murine double minute 2} & F: CATTGAACCTTGTGTGATTTGTC \\
\hline & & R: GCAGGGCTTATTCCTTTTCTTTA \\
\hline \multirow[t]{2}{*}{$B A X$} & \multirow[t]{2}{*}{ BCL2-associated X } & F: CCTGTGCACCAAGGTGCCGGAACT \\
\hline & & R: CCACCCTGGTCTTGGATCCAGCCC \\
\hline \multirow[t]{2}{*}{ CASP3 } & \multirow[t]{2}{*}{ Caspase-3 } & F: ACATGGCGTGTCATAAAATACC \\
\hline & & R: CACAAAGCGACTGGATGAAC \\
\hline \multirow[t]{2}{*}{$G A P D H$} & \multirow[t]{2}{*}{ Glyceraldehyde 3-phosphate dehydrogenase } & F: CACATGGCCTCCAAGGAGTAA \\
\hline & & R: TGAGGGTCTCTCTCTTCCTCTTGT \\
\hline
\end{tabular}

of annexin $\mathrm{V}$ binding buffer (140 $\mathrm{mm} \mathrm{NaCl}, 10 \mathrm{~mm}$ HEPES/NaOH, $2.5 \mathrm{~mm} \mathrm{CaCl}_{2}$ ). The suspension was stained with $5 \mu \mathrm{l}$ of annexin $\mathrm{V}$ FITC and $5 \mu \mathrm{l}$ of PI, then incubated for $15 \mathrm{~min}$ at RT in the dark. To the sample was added $250 \mu \mathrm{l}$ of $1 \times$ phosphate-buffered saline, this was then centrifuged at $1,000 \times g$ for $5 \mathrm{~min}$ at RT, and cells were resuspended in $50 \mu \mathrm{l}$ of annexin V binding buffer. Stained cells were then analyzed on a Cellometer K2 image cytometer (Nexcelom Bioscience, Lawrence, MA, USA).

Isolation of RNA and real-time polymerase chain reaction. Total RNA was extracted from untreated and treated breast cancer cell lines, MCF-7 and MDA-MB-231, using Trizol and quantified on a NanoDrop spectrophotometer (Nanodrop 2000; Thermo Scientific, Waltham, MA, USA). Purity was estimated by $260 / 280 \mathrm{~nm}$ absorbance ratio. cDNA was synthesized using the High-Capacity cDNA Reverse Transcription kit (Applied Biosystems, Courtaboeuf, France). Quantitative real-time PCR analysis was performed using a SYBR Green PCR Master Mix (Applied Biosystems, Courtaboeuf, France) as follows: first step at $50^{\circ} \mathrm{C}$ for $2 \mathrm{~min}$, denaturation step at $95^{\circ} \mathrm{C}$ for $10 \mathrm{~min}$, then 40 cycles at $95^{\circ} \mathrm{C}$ for $15 \mathrm{~s}$ and $60^{\circ} \mathrm{C}$ for $1 \mathrm{~min}$. In total, $10 \mathrm{ng}$ of cDNA was added to $18 \mu \mathrm{l}$ of reaction containing primers. Relative expression levels of $p 53, M D M 2$ and BCL2-associated X $(B A X)$ were calculated using the $2^{-\Delta \Delta C t}$ method. Experiments were repeated in triplicate. The primer sequences used are listed in Table II.

Data analysis. Data are expressed as the mean \pm SEM of multiple experiments. Statistical significance was determined by Student's $t$ test using SPSS software (ver. 18.0; SPSS Inc., Chicago, IL, USA).

\section{Results}

Effects of spiro-bisheterocycles 2-7 on MCF-7 and MDA-MB231 cell proliferation. In order to determine the impact of spirobisheterocycles 2-7 on cell proliferation of human breast cancer cell lines, MCF-7 and MDA-MB 231 cells were treated with compounds 2-7 at different concentrations from 10 to $100 \mu \mathrm{M}$ for $72 \mathrm{~h}$. Cell proliferation was assessed after $2 \mathrm{~h}$ of incubation with resazurin solution. Proliferation of $\mathrm{MCF}-7$ human breast cancer cell line was significantly reduced with compounds $\mathbf{3}$ and $\mathbf{6}$, with The half-maximal inhibitory concentration $\left(\mathrm{IC}_{50}\right)$ corresponding to $42.3 \mu \mathrm{M}(17.4 \mu \mathrm{g} / \mathrm{ml})$ and $66.3 \mu \mathrm{M}(30.8 \mu \mathrm{g} / \mathrm{ml})$ (Figure 3), respectively. We also observed significant inhibition of MDA-MB-231 cells (Figure 3) up to $67.9 \mu \mathrm{M}(28.5 \mu \mathrm{g} / \mathrm{ml})$ for 3 and $97.1 \mu \mathrm{M}(42.7 \mu \mathrm{g} / \mathrm{ml})$ for $\mathbf{6}$. Proliferation of MDA-MB 231 cells was also significantly reduced with compound 4, with $\mathrm{IC}_{50}$ of $44.6 \mu \mathrm{M}(19.6 \mu \mathrm{g} / \mathrm{ml})$, but not of MCF-7 cells. On the other hand, treatment with compounds $\mathbf{2 , 5}$ and $\mathbf{7}$ did not induce a significant decrease in cell proliferation in the two breast cancer cell lines. At a $100 \mu \mathrm{M}$, compound $\mathbf{3}$ was the most effective, inducing a major suppressive effect of $98.15 \%$ and $97.02 \%$ against MCF-7 and MDA-MB 231 cells, respectively.

Hoechst staining confirmed results of the resazurin assay and showed significant impact of compounds $\mathbf{3}$ and $\mathbf{6}$ on MCF-7 and MDA-MB-231 tumor cell proliferation (Figure 4), with similar $\mathrm{IC}_{50}$. Compound 4 induced tumor inhibition at an $\mathrm{IC}_{50}$ of $42 \mu \mathrm{M}$ inMDA-MB-231 cells.

Effects of spiro-bisheterocycles 3, 4 and $\mathbf{6}$ on apoptosis. In order to determine the apoptotic efficacy of the spirobisheterocycles, cells were treated with $100 \mu \mathrm{M}$ of $\mathbf{3 , 4}$ and 6 for $72 \mathrm{~h}$ (Figure 5), then collected and subjected to Cellometer annexin V-FITC/PI apoptosis assay. Annexin V$\mathrm{FITC}^{-} / \mathrm{PI}^{-}$flagged viable cells, annexin $\mathrm{V}-\mathrm{FITC}^{+} / \mathrm{PI}^{-}$flagged early-stage apoptotic cells, and annexin $\mathrm{V}-\mathrm{FITC}^{+} / \mathrm{PI}^{+}$flagged late-stage apoptotic cells.

Analysis showed a sharp induction of apoptosis by compounds 3 and 6 in MCF-7 cells and by 3,4 and 6 in MDA-MB-231 cells (Figure 5A). The rates of early and late apoptosis were $9.5 \%, 85.4 \%$ and $71.3 \%$ in $\mathrm{MCF}-7$ for control, and compounds 3 and $\mathbf{6}$, respectively, and $5.9 \%$, $88.1 \%, 79.4 \%$ and $66.4 \%$ in MDA-MB-231 cells for control, and compounds $\mathbf{3}, \mathbf{4}$ and $\mathbf{6}$, respectively (Figure 5B).

Effects of spiro-bisheterocycles 3, 4 and 6 on p53, MDM2, $B A X$ and caspase 3 expression. In an effort to investigate whether spiro compounds $\mathbf{3}, \mathbf{4}$ and $\mathbf{6}$ induce apoptosis of breast cancer cell lines by targeting p53-MDM2 interaction, we used quantitative reverse transcription-polymerase chain reaction to analyze the wild-type $p 53, M D M 2, B A X$ and 

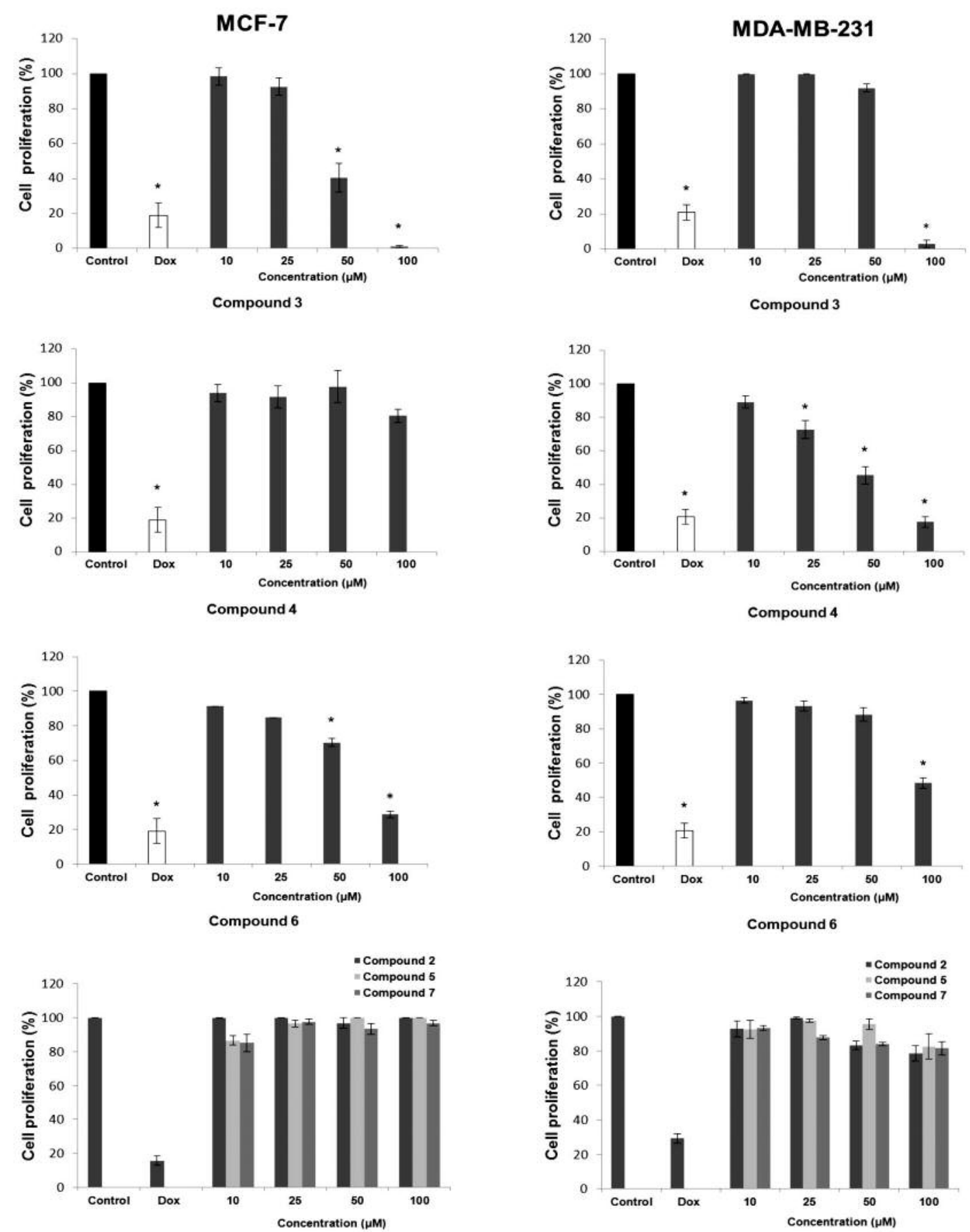

Figure 3. Effect of compounds 2-7 on the in vitro growth and proliferation of human breast cancer cells. MCF-7 and MDA-MB231 cell line were either untreated, treated with $1 \mu \mathrm{M}$ doxorubicin (Dox) or treated with 10, 25, 50 and $100 \mu \mathrm{M}$ of compounds 2-7 for $72 \mathrm{~h}$ as described in the Materials and Methods section. Proliferation was assessed using resazurin on an automated 96-well Fluoroskan Ascent FL. Columns show means $\pm S D, n=6$. *Significantly different at $p<0.05$.

caspase 3 gene expression levels. Results for MCF-7 breast cancer cells show that compound $\mathbf{3}$ more clearly increased the expression of wild-type p53 (6.707-fold $v s$. control) than did compound 6 (3.275-fold $v s$. control) (Figure 6). We also found that compounds 3 and $\mathbf{6}$ induced up-regulation of $M D M 2$ in MCF-7 cells at levels of 4.282 and 2.658, respectively. However, in MDA-MB-231 p53-mutant breast cancer cells, no significant changes in the levels of $p 53$ and $M D M 2$ were 

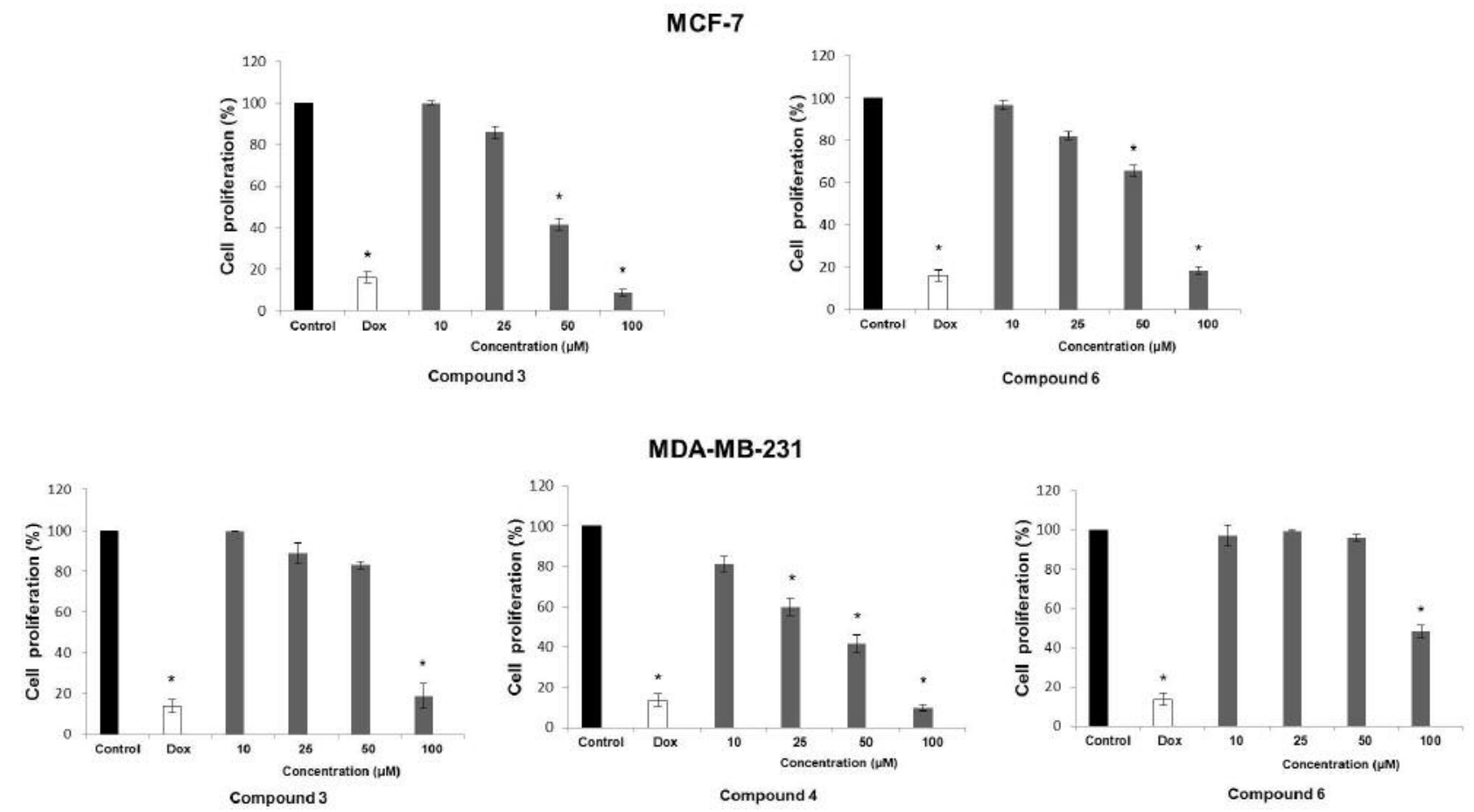

Figure 4. Inhibitive effect of compounds 3, 4 and $\mathbf{6}$ on growth of cancer cell lines MCF-7 and MDA-MB-231. *Significantly different at p<0.05.

observed with compounds $\mathbf{3}, \mathbf{4}$ and $\mathbf{6}$, indicating that overexpression of MDM2 is under control of $p 53$. Compared to levels in untreated control MCF-7 cells, compounds 3 and 6 led to 6.738- and 3.532-fold higher $B A X$ and 6.498- and 2.703-fold higher caspase $\mathbf{3}$ gene expression, respectively. Interestingly, similar results were obtained in MDA-MB-231 cells, where an increase of the expression of caspase 3 and $B A X$ genes was also noted with compounds $\mathbf{3}, \mathbf{6}$ and, even with compound 4 . This demonstrates the capacity of our compounds to induce apoptosis independently of p53 status.

\section{Discussion}

Tumor suppressor p53 plays a key role in the regulation of cell cycle and apoptosis (13-15). We previously reported that p53 inhibition by its negative regulator MDM2 is involved in the onset of breast cancer $(16,17)$. An approach based on restoring p53 activity by inhibiting p53-MDM2 interaction could lead to tumor suppression and thus be a promising strategy for future control of breast cancer $(18,19)$. Many spiro compounds possess very promising biological and pharmacological activities, especially antitumor and antimicrobial properties $(4,20,21)$.

These specific, potent, non-peptide small-molecule inhibitors are reported to mimic the $\alpha$-helix recognition motif of the p53-
MDM2 complex (22), thereby efficiently reactivating p53 tumor-suppressor activity and consequently inducing a p53mediated signaling pathway that will culminate in cell death by apoptosis (23). Our results clearly showed that the spiroheterocyclic compounds substituted by isoxazole (3), diazepine (4) and oxazepine (6) significantly reduced the proliferation of MCF-7 and MDA-MB-231 cells in a dose-dependent manner. These results were consistent with other studies demonstrating the cytotoxicity of spiro-bicyclic compounds in human cancer cell lines $(5,24)$. Our data are further supported by another report which demonstrated similar in vivo anticancer potential of a spiro-heterocyclic compound on the development on MCF-7 human breast cancer cells (25). The antiproliferative effect was more pronounced with spiro-isoxazole (3). Structurally, the presence of the isoxazole heterocyclic unit is likely tightly related to these clear antiproliferative effects, as already reported for other spiro-models containing the isoxazole motif (7). It was also observed that the presence of oxazepine substituent demonstrated good activity against breast cancer cells (26), thus explaining the antiproliferative effect observed with compound 6. Furthermore, the significant antiproliferative activity of compound $\mathbf{4}$ could stem from the presence of a diazepine molecule in the structure, since diazepine inhibits the adenosine $\mathrm{A} 2 \mathrm{~B}$ receptor involved in the development of tumors and proliferation (27). In addition, a 
A
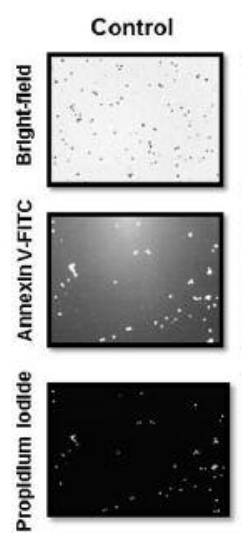

B



MCF-7


MCF-7
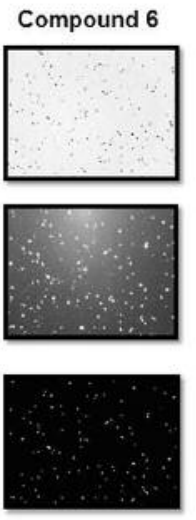
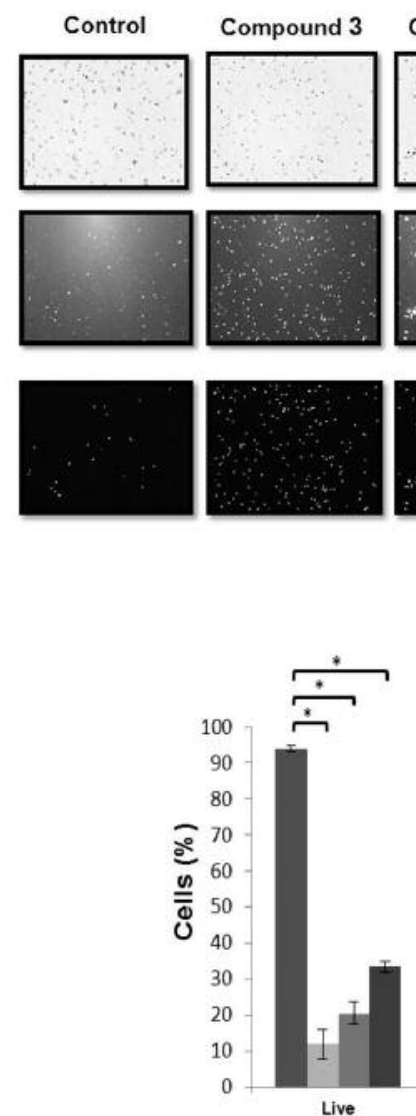

MDA-MB-231
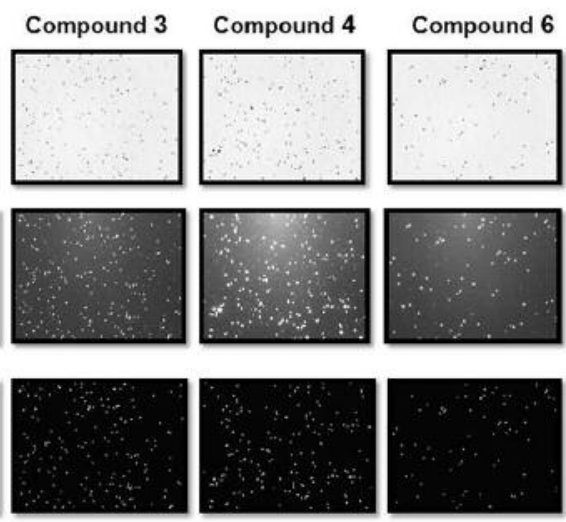

Compound 3

- Compound 4

- Compound 6

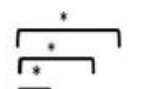

$\square$

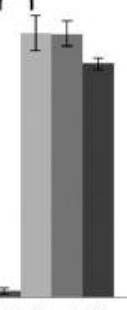

Early Apoptotic Late Apoptotic

Figure 5. Drug-induced apoptosis in breast cancer cell lines MCF-7 and MDA-MB-231 at 72 h of incubation with spiro-bisheterocyclic compounds. A: Bright-field (top row), and fluorescent images of annexin V-fluorescein isothiocyanate (FITC) (middle row) and propidium iodide (PI) (bottom row) staining. The images show significant induction of apoptosis with compounds 3 and 6 in MCF-7cells, while strong apoptosis was observed with compounds 3, 4 and 6 in MDA-MB-231 cells. B: Quantitative results of percentage of viable, and early apoptotic and late apoptotic cells after treatment with compounds. *Significantly different at $p<0.05$.

previous study reported that adenosine $\mathrm{A}_{2 \mathrm{~B}}$ receptors are expressed at high levels in the estrogen-negative MDA-MB231 cell line but not expressed in the estrogen-positive MCF7 cell line, which could explain why the antiproliferative effect of compound 4 was observed here only in MDA-MB-231 cells (28). Moreover, the presence of cyclohexyl fragments in these three compounds might also contribute to their antiproliferative activity (29), allowing better understanding of why compounds 5 and $\mathbf{7}$ had no effect.

Apoptosis plays a key role in the maintenance of homeostasis (30) and is considered a primary form of cancer cell death (31). This pathway results in DNA fragmentation, degradation of cytoskeletal and nuclear proteins, formation of apoptotic bodies, and finally uptake by phagocytic cells (32). Recent reports indicate that most spiro compounds induce apoptosis of cancer cells $(33,34)$, but especially spiroisoxazolidine derivatives (35). Here, we performed annexin V-
FITC/PI apoptosis assays and demonstrated that our spirobisheterocyclic compounds induced apoptosis of breast cancer cell lines. Annexin V is a protein that interacts strongly and specifically with phosphatidylserine. During early apoptosis, phosphatidylserine translocates to the external leaflet and can be used for the detection of apoptosis (36). Analysis using Cellometer K2 image cytometry indicated that compounds $\mathbf{3}$, 4 and 6 induced a large proportion of breast cancer cell death by apoptosis in vitro. The strong effect was observed with compound $\mathbf{3}$ in both breast cancer cell lines.

As previously demonstrated (18), the most likely mechanism by which spiro compounds initiate apoptosis of wild-type $p 53$ breast cancer cells is by inhibition and disruption of the p53-MDM2 interaction, leading to accumulation of p53 and up-regulation of MDM2. The tumor suppressor p53 binds to DNA and mediates transcriptional activation which ultimately overexpress BAX and promote 




MDA-MB-231
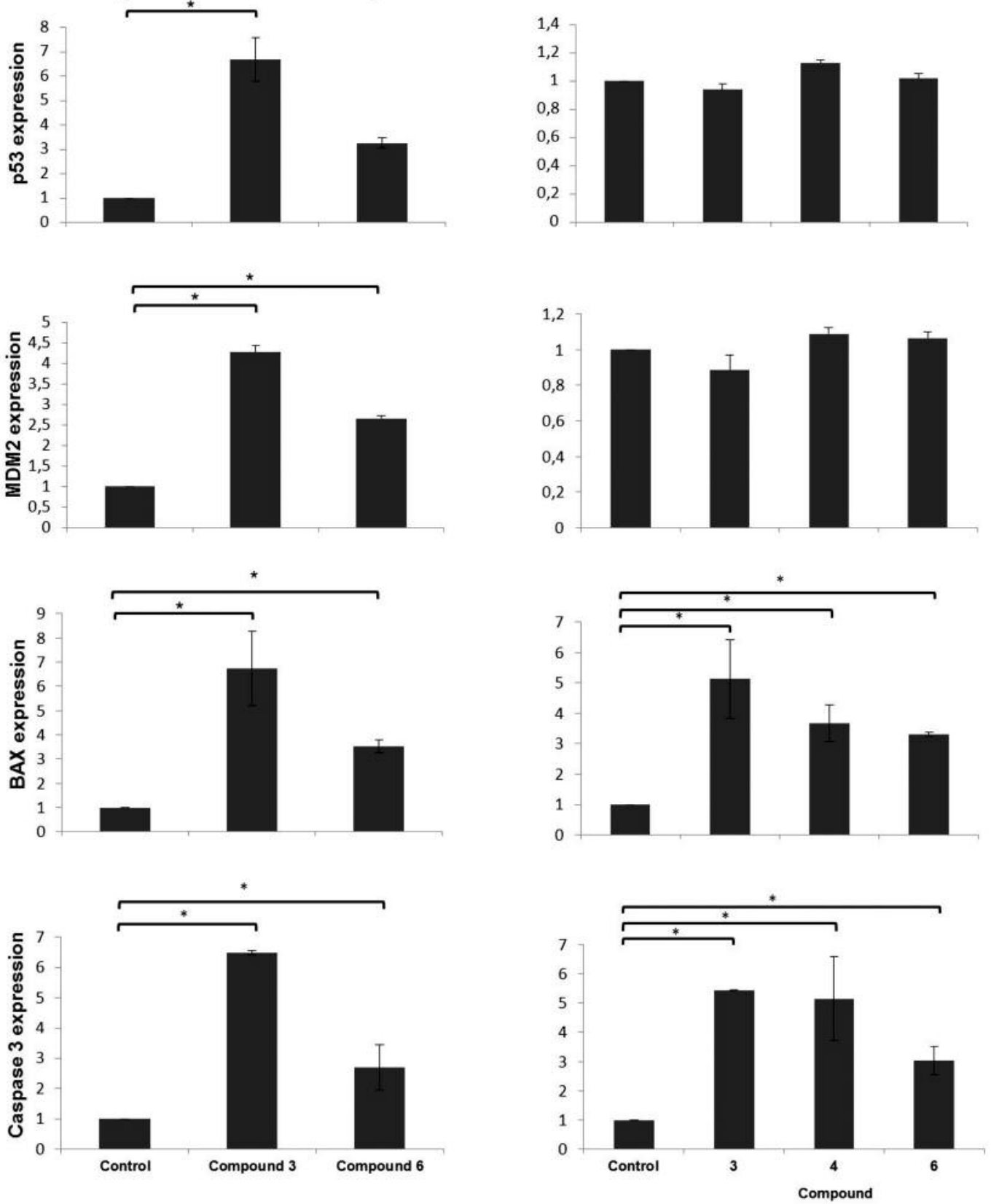

Figure 6. Results of polymerase chain reaction detection.p53, murine double minute 2 (MDM2), BCL2-associated X (BAX) and caspase-3 genes expression in MCF-7 and MDA-MB-231 cells following treatment with $100 \mu \mathrm{M}$ of compounds $\mathbf{3}, 4$ and 6 for $72 \mathrm{~h}$. *Significantly different at $p<0.05$.

p53-dependent cell apoptosis $(37,38)$. The pro-apoptotic $\mathrm{BAX}$ protein is one of the most important regulators of the intrinsic pathway of apoptosis (39). Excess of BAX protein leads to formation of BAX-BAX homodimers, that stimulate release of cytochrome $c$ from mitochondria and activate caspase-3, then inducing apoptosis (40).
Quantitative reverse transcription-polymerase chain reaction data support these findings and showed an increase of wild-type p53 expression in MCF-7 cells, accompanied by up-regulation of $M D M 2$, with treatment of compound 3 and 6 . We extended this study by demonstrating that spiro compounds 3 and $\mathbf{6}$ enhance expression of caspase- 3 and 
p53-Dependent pathway
p53-Independent

pathway



Figure 7. Proposed mechanisms of apoptosis of breast cancer MCF-7 and MDA-MB-231 cells induced by spiro-compounds 3, 4 and 6.

BAX in MCF-7 wild-type p53 breast cancer cells, and consequently induce apoptosis. At the same time, in order to determine whether our spiro compounds induce apoptosis regardless of cell p53 status, we also employed MDA-MB231 cells which harbor mutant $p 53$. Treatment with compounds 3,4 and 6 had no significant effect on expression of p53 or MDM2 in cancer cells lacking wild-type p53 but increased caspase-3 and $B A X$ expression. These results correlate with a previous study revealing induction of apoptosis through p53-independent pathways (41).

In summary (Figure 7), this study brings the first demonstration that new small spiro-bisheterocyclic molecules can sensitize breast cancer cells to apoptosis by targeting p53-MDM2 interaction. We also highlighted that these spiro compounds promote apoptosis via p53independent pathway(s), suggesting that these compounds represent interesting candidates as therapeutic targets for the treatment of breast cancer.

\section{Acknowledgements}

The Authors thank the Unité de Nutition Humaine UMR 1019 INRA-UdA - Equipe ECREIN (France) and the University of Aveiro, Fundação para a Ciência e a Tecnologia (Portugal), EU, QREN, FEDER, COMPETE, for funding this biological and organic chemistry research. They also thank Algeria's General Directorate for Scientific Research and Technological Development (DGRSDT) for financial support.

\section{References}

1 Ferlay J, Shin HR, Bray F, Forman D, Mathers C and Parkin DM: Estimates of worldwide burden of cancer in 2008. Int J Cancer 127: 2893-2917, 2010.

2 Rokhlin OW, Gudkov AV, Kwek S, Glover RA, Gewies AS and Cohen MB: p53 is involved in tumor necrosis factor-alphainduced apoptosis in the human prostatic carcinoma cell line LNCaP. Oncogene 19: 1959-1968, 2000.

3 El-Hashash MA, Rizk SA and Atta-Allah SR: Synthesis and regioselective reaction of some unsymmetrical heterocyclic chalcone derivatives and spiro heterocyclic compounds as antibacterial agents. Molecules 20: 22069-22083, 2015.

4 Miao Y, Juan X, Jing-Jing Z, Jun-Lin H, Yun Z, Hui F, Yang GX, $\mathrm{Xia} \mathrm{G}$ and $\mathrm{Hu} \mathrm{JF}$ : Leonurusoleanolides E-J, minor spirocyclic triterpenoids from Leonurus japonicus fruits. J Nat Prod 77: 178-182, 2014.

5 Moujir LM, Seca AM, Araujo L, Silva AM and Barreto MC: A new natural spiro heterocyclic compound and the cytotoxic activity of the secondary metabolites from Juniperus brevifolia leaves.Fitoterapia 82: 225-229, 2011.

6 Ding K, Lu Y, Nikolovska-Coleska Z, Qiu S, Ding Y, Gao W, Stuckey J, Krajewsk,i K, Roller PP, Tomita Y, Parrish DA, Deschamps JR and Wang S: Structure-based design of potent non-peptide MDM2 inhibitors. J Am Chem Soc 127: 1013010131, 2005.

7 Das P, Omollo AO, Sitole LJ, McClendon E, Valente EJ and Raucher D: Synthesis and investigation of novel spiro-isoxazolines as anti-cancer agents. Tetrahedron Lett 56: 1794-1797, 2015.

8 Vassilev LT: MDM2 inhibitors for cancer therapy. Trends Mol Med 13: 23-31, 2007. 
9 Yin Y, Stephen CW, Luciani MG and Fahraeus R: P53 stability and activity is regulated by MDM2-mediated induction of alternative p53 translation products. Nat Cell Biol 4: 462-467, 2002.

10 Wade M, Li YC and Wahl GM: MDM2, MDMX and p53 in oncogenesis and cancer therapy. Nat Rev Cancer 13: 83-96, 2013.

11 Talhi O, Pinto DCGA, Paz FAA, Hamdi, M and Silva AMS: Synthesis and ring transformation ofoxygen and nitrogen spirobisheterocycles. Synlett 26: 167-172, 2015.

12 Dubois V, Jardé T, Delort L, Billard H, Bernard-Gallon D, Berger E, Geloen A, Vasson MP and Caldefie-Chezet F: Leptin induces a proliferative response in breast cancer cells but not in normal breast cells. Nutr Cancer 66: 645-655, 2014.

13 El-Deiry WS: Regulation of p53 downstream genes. Semin Cancer Biol 8: 345-357, 1998.

14 Levine AJ: p53, the cellular gate keeper for growth and division. Cell 88: 323-331, 1997.

15 Vogelstein B, Lane D and Levine AJ: Surfing the p53 network. Nature 408: 307-310, 2000.

16 Rayburn E, Zhang R, He J and Wang H: MDM2 and human malignancies: expression, clinical pathology, prognostic markers, and implications for chemotherapy. Curr Cancer Drug Targets 5: 27-41, 2005.

17 Vassilev LT, Vu BT, Graves B, Carvajal D, Podlaski F, Filipovic Z, Kong N, Kammlott U, Lukacs C, Klein C, Fotouhi N and Liu EA: In vivo activation of the p53 pathway by small-molecule antagonists of MDM2. Science 303: 844-848, 2004.

18 Shangary S, Qin D, McEachern D, Liu M, Miller RS, Qiu S, Nikolovska-Coleska Z, Ding K, Wang G, Chen J, Bernard D, Zhang J, Lu Y, Gu Q, Shah RB, Pienta KJ, Ling X, Kang S, Guo M, Sun Y, Yang D and Wang S: Temporal activation of p53 by a specific MDM2 inhibitor is selectively toxic to tumors and leads to complete tumor growth inhibition. Proc Natl Acad Sci USA 105: 3933-3938, 2008.

19 Shangary, S and Wang S: Targeting the MDM2-p53 interaction for cancer therapy. Clin Cancer Res 14: 5318-5324, 2008.

20 Rompaey KV, Ballet S, Tömböly C, Wachter RD, Vanommeslaeghe K, Biesemans M, Willem R and Tourwé DA: Synthesis and evaluation of the $\beta$-turn properties of 4 -amino1,2,4,5-tetrahydro-2-benzazepin-3-ones and of their spirocyclic derivative.Eur J Org Chem 13: 2899-2911, 2006.

21 Rosy P, Manabendra P, Behera, AK, Mishra BK and Behera RK: A synthon approach to spiro compounds. Tetrahedron 62: 779828,2006

22 Somu RV and Johnson RL: Synthesis of pipecolic acid-based spiro bicyclic lactam scaffolds as $\beta$-turn mimics. J Org Chem 70: 5954-5963, 2005.

23 Shangary S and Wang S: Small-molecule inhibitors of the MDM2-p53 protein-protein interaction to reactivate p53 function: a novel approach for cancer therapy. Annu Rev Pharmacol Toxicol 49: 223-241, 2009.

24 Manner S, Oltner VT, Oredsson S, Ellervik U and Frejd T: Spiro-bicyclo[2.2.2] octane derivatives as paclitaxel mimetics. Synthesis and toxicity evaluation in breast cancer cell lines. Org Biomol Chem 7: 7134-44, 2013.

25 Chin YW, Salim AA, Su BN, Mi Q, Chai, HB, Riswan S, Kardono LB, Ruskandi A, Farnsworth NR, Swanson SM and Kinghorn AD: Potential anticancer activity of naturally occurring and semisynthetic derivatives of aculeatins A and B from Amomum aculeatum. J Nat Prod 71: 390-395, 2008.
26 Dhanya S, Ranjitha C, Rama M and KSR P: Oxazepine derivative as an antitumor agent and SNAIL1 inhibitor against human colorectal adenocarcinoma. Int J Innov Res Sci Eng Technol 3(8): 15357-15363, 2014.

27 Hoffmann K, Xifró RA, Hartweg JL, Spitzlei P, Meis K, Molderings GJ and von Kügelgen I: Inhibitory effects of benzodiazepines on the adenosine $\mathrm{A}(2 \mathrm{~B})$ receptor mediated secretion of interleukin-8 in human mast cells. Eur J Pharmacol 700: 152-158, 2013.

28 Panjehpour M, Castro M and Klotz KN: Human breast cancer cell line MDA-MB-231 expresses endogenous A2B adenosine receptors mediating a $\mathrm{Ca}^{2+}$ signal. Br J Pharmacol 145: 211-218, 2005.

29 Bhat MA, Al-Dhfyan A, Naglah AM, Khan AA and Al-Omar MA: Lead optimization of 2-cyclohexyl- $N$-[(Z)-(3-methoxyphenyl/3hydroxyphenyl) methylidene]hydrazine-carbothioamides for targeting the HER-2 overexpressing breast cancer cell line SKBr3. Molecules 20: 18246-18263, 2015.

30 Norbury CJ and Hickson ID: Cellular responses to DNA damage. Annu Rev Pharmacol Toxicol 41: 367-401, 2001.

31 Elmore S: Apoptosis: A review of programmed cell death. Toxicol Pathol 35: 495-516, 2007.

32 Martinvalet D, Zhu P and Lieberman J: Granzyme A induces caspase-independent mitochondrial damage, a required first step for apoptosis. Immunity 22: 355-370, 2005.

33 Molvi KI, Haque N, Awen BZS and Zameeruddin M: Synthesis of spiro compounds as medicinal agents; new opportunities for drug design and discovery. World J Pharm Sci 3: 536-563, 2014.

34 Yu B, Shi XJ, Qi PP, Yu DQ and Liu HM: Design, synthesis and biological evaluation of novel steroidal spiro-oxindoles as potent antiproliferative agents. J Steroid Biochem Mol Biol 141: 121134, 2014.

35 Khazir J, Singh PP, Reddy DM, Hyder I, Shafi S, Sawant SD, Chashoo G, Mahajan A, Alam MS, Saxena AK, Arvinda S, Gupta BD and Kumar HM: Synthesis and anticancer activity of novel spiro-isoxazoline and spiro-isoxazolidine derivatives of $\alpha$ santonin. Eur J Med Chem 63: 279-289, 2013.

36 Sean RS, Arthur CM, Ju T, Rodrigues LC, Riul TB, Dias-Baruffi M, Miner J, McEver RP and Cummings RD: Galectin-1 induces reversible phosphatidylserine exposure at the plasma membrane. Mol Biol Cell 20: 1408-1418, 2009.

$37 \mathrm{Li} \mathrm{B}$ and Dou QP: BAX degradation by the ubiquitin/ proteasome-dependent pathway: involvement in tumor survival and progression. Proc Natl Acad Sci USA 97: 3850-3855, 2000.

38 Scheffner M, Werness BA, Huibregtse JM, Levine AJ and Howley PM: The E6 oncoprotein encoded by human papillomavirus types 16 and 18 promotes the degradation of $\mathrm{p} 53$. Cell 63: 1129-1136, 1990.

39 Williams GT and Smith CA: Molecular regulation of apoptosis: genetic controls on cell death. Cell 74: 777-779, 1993.

40 Kurabayashi A1, Furihata M, Matsumoto M, Ohtsuki Y, Sasaguri $\mathrm{S}$ and Ogoshi S. Expression of BAX and apoptosis-related proteins in human esophageal squamous cell carcinoma including dysplasia. Mod Pathol 14: 741-747, 2001.

41 Lanni JS, Lowe SW, Licitra EJ, Liu JO and Jacks T: p53independent apoptosis induced by paclitaxel through an indirect mechanism. Proc Natl Acad Sci USA 94: 9679-9683, 1997.

Received October 12, 2016

Revised November 2, 2016

Accepted November 9, 2016 